\title{
Hasil Kandungan Agar Ekstraksi Non-Alkali Gracilaria sp. yang Tumbuh di Lingkungan Berbeda
}

\author{
Prismabella Wilis Andiska*, AB. Susanto, Rini Pramesti \\ Departemen IImu Kelautan, Fakultas Perikanan dan IImu Kelautan, Universitas Diponegoro \\ JI. Prof.H.Soedarto S.H, Tembalang, Semarang, Jawa Tengah 50275 Indonesia \\ Corresponding author, e-mail : andiskawilis@gmail.com
}

\begin{abstract}
ABSTRAK: Gracilaria sp. merupakan rumput laut merah penghasil agar yang banyak digunakan untuk industri pangan maupun non pangan lainnya. Ekstraksi ini umumnya menggunakan alkali yang berdampak pada lingkungan dan keamanan bahan pangan. Informasi tentang ekstraksi perlakuan non alkali di Indonesia untuk industri pangan diduga belum ada sehingga penelitian ini perlu dilakukan. Tujuan penelitian ini untuk mengkaji apakah ekstraksi non alkali dari Gracilaria sp. dapat menghasilkan agar, rendemen, kandungan proksimat serta dianalisis FTIR dari kedua lokasi yang berbeda (laut dan tambak). Metode ekstraksi dilakukan dengan merebus sampel kering hingga didapatkan agar, yang selanjutnya dikeringkan dan dijadikan tepung. Hasil penelitian menunjukkan ekstraksi perlakuan non alkali dari kedua lokasi dapat menghasilkan rendemen dengan nilai rendah (14-15,31\%). Kadar air tertinggi $(15,40 \pm 0,59 \%)$ terdapat pada agar sampel dari laut, kadar abu tertinggi $(41,45 \pm 0,59 \%)$ pada sampel kering dari laut, kadar protein tertinggi $(8,59 \pm 0,26 \%)$ pada sampel kering dari tambak, kadar lemak tertinggi $(0,63 \pm 0,13 \%)$ pada agar sampel dari laut, dan karbohidrat tertinggi $(67,19 \pm 0,86 \%)$ pada sampel kering dari tambak. Hasil FTIR menunjukkan agar mengandung komposisi gugus galaktosa 3,6-anhydro-L-galaktosa.
\end{abstract}

Kata kunci: Gracilaria sp.; Agar; Ekstraksi Non Alkali; Proksimat; FTIR

\section{Agar Content of Non-Alkaline Extraction of Gracilaria sp. from Different Environment}

ABSTRACT: Gracilaria sp. is a red seaweed which is known as an agarophyte and widely used for food and other non-food industries. Generally agar extraction uses alkali which has an environmentally impact and food safety. Non-alkaline extraction treatment for food grade is still under observed in Indonesia. The purpose of this research is to access whether agar extraction of Gracilaria sp. can be carried out, as well as the amount of agar yield, proximate contents and FTIR analysis from two different locations. The extraction method is done by boiling a dry sample to obtain agar, which is then dried and turned into flour. The results showed that the extraction of non-alkaline treatment could be carried out on Gracilaria sp. with low yield (14-15.31\%). The highest water content $(15.40 \pm 0.59 \%)$ found in agar from dried seaweed form the sea, highest ash $(41.45 \pm 0.91 \%)$ in dried seaweed from the sea, highest protein $(8.59 \pm 0.26 \%)$ in dried cultured seaweed, highest fat $(0.63 \pm 0.13 \%)$ in agar from the sea, and highest carbohydrate $(67.19 \pm 0.86 \%)$ in dried cultured seaweed. FTIR analysis showed that the agars contained a composition of galactose groups of 3,6-anhydro-L-galaktose.

Keywords: Gracilaria sp.; Agar; Extraction of Non-Alkaline; Proximate; FTIR

\section{PENDAHULUAN}

Agar merupakan sebuah polisakarida kompleks yang umumnya diekstraksi dari Gracilaria sp., Gelidium sp., Gelidiella sp., Pterocladia sp., dll. Penggunaan $80 \%$ sebagai bahan makanan dan sisanya untuk aplikasi bioteknologi (Saraswaty et al., 2015). Kualitas agar terbaik diperoleh dari Gelidium dan Gracilaria (Ahmad et al., 2011).

Metode ekstraksi untuk menghasilkan agar umumnya menggunakan pra perlakuan alkali untuk meningkatkan kekuatan agar (Yousefi et al., 2013) dan fikokoloid (Rhein-Knudsen et al., 2017). Kekurangan penggunaan alkali (Lee et al., 2016) menghasilkan limbah yang mengandung zat pemutih (Villanueva \& Montano, 2014) dan residu alkali dalam produk konsumsinya 
(Hernandez-Carmona et al., 2013). Metode ekstraksi non alkali dari Gracilaria dengan merebus dalam air/air suling pada suhu $90-95^{\circ} \mathrm{C}$ (Ahmad et al., 2011; Sahu \& Sahoo, 2013; Yarnpakdee et al., 2015). Agar jenis ini bukan untuk industri bakteriologis, namun digunakan untuk industri makanan (Torres et al., 2019). Penggunaan agar tanpa alkali perlu dikembangkan di Indonesia karena produksi Gracilaria yang melimpah.

Perlakuan non alkali dalam proses ekstraksi dapat meningkatkan kandungan agar namun kajian tentang penggunaan untuk bahan makanan diduga belum ada informasi. Tujuan penelitian ini untuk memperoleh agar dari Gracilaria sp. secara non alkali, kandungan proksimat dan analisis FTIR untuk mengetahui penggunaan agar dari kedua lokasi yang berbeda yaitu di tambak dan di laut.

\section{MATERI DAN METODE}

Materi yang digunakan adalah rumput laut Gracilaria sp. yang diambil dari Pantai Pok Tunggal, Gunung Kidul dan tambak Desa Randusanga, Brebes. Kualitas perairan (suhu, salinitas, $\mathrm{DO}, \mathrm{pH}$, dan kecerahan) diukur. Sampel yang telah diperoleh dicuci untuk menghilangkan garam dan kotoran, dikeringkan, yang selanjutnya direndam dalam air tawar semalam dalam suhu ruangan (Al-Nahdi et al., 2015) lalu dikeringkan selama 3 hari.

Pembuatan agar (Yarnpakdee et al., 2015) dilakukan dengan ekstraksi perlakuan non alkali. Ekstraksi dilakukan dengan merebus sampel yang telah dipotong dalam air mendidih sebanyak $4000 \mathrm{~mL}$ pada suhu $\pm 95^{\circ} \mathrm{C}$ selama 3 jam. Filtrat disaring kemudian dibiarkan membentuk gel pada suhu ruangan dan didinginkan. Agar dikeringkan hingga diperoleh lembaran kering, selanjutnya diblender menjadi tepung. Masing-masing ekstraksi dengan 3 ulangan.

Parameter yang diamati hasil rendemen, uji proksimat agar yang meliputi kadar air, kadar abu, kadar protein, kadar lemak, dan karbohidrat. Analisis Fourier Tranform Infrared (FTIR) dilakukan untuk mengetahui keberadaan gugus-gugus fungsi molekulnya.

\section{HASIL DAN PEMBAHASAN}

Rendemen agar diperoleh dari perbandingan antara berat akhir agar dengan berat awal rumput laut kering yang diekstraksi. Rendemen yang diperoleh dari laut yaitu 15,31 $\pm 0,48 \%$, sedangkan dari tambak yaitu $14 \pm 0,15 \%$ (Tabel 1).. Hasil ini lebih kecil apabila dibandingkan dengan standar yaitu 25\% (BSN, 2015). Hasil penelitian ini sesuai 9,65-18,64\% (Cirik et al., 2010) dan 9-13,5\% (Ahmad et al., 2011), namun masih lebih rendah dari 17,1\% (Yarnpakdee et al., 2015). Agar ekstraksi alkali memiliki rendemen lebih tinggi yaitu 23-26\% (Yarnpakdee et al., 2015). Rendahnya rendemen agar hasil ekstraksi perlakuan non alkali diduga agar larut dalam air selama perendaman pra ekstraksi dan hilang saat dicuci. Agar yang diekstraksi tanpa alkali membuat thalus lebih lunak dibandingkan dengan alkali. Larutan ini membuat thalus kaku sehingga menghambat larutnya kandungan agar saat pencucian (Villanueva et al., 2010). Rendahnya rendemen juga diduga tingginya kadar abu. Kadar abu pada agar yang diperoleh memiliki nilai tinggi dan melebihi standar (Tabel 2), sehingga dapat menghambat difusi agar dalam air. Tinggi rendahnya rendemen agar dipengaruhi jenis rumput laut, proses ekstraksi, kondisi lingkungan, distribusi geografis dan musim panen (Santika et al., 2014; Ibrahim et al., 2015). Kadar air tertinggi terdapat pada agar dari laut yaitu $15,40 \pm 0,59 \%$ dan terendah pada sampel kering dari tambak yaitu $9,17 \pm 0,50 \%$. Hasil ini sesuai standar mutu yaitu kurang dari $12 \%$ dan agar tepung kurang dari 22\% (BSN, 2015). Kadar air rumput laut kering yang diperoleh lebih rendah dibanding dengan Gracilaria dari laut (Diana et al., 2014; Ate et al., 2017; Kasimala et al., 2017) dan dari tambak (Cirik et al., 2010; Diana et al., 2014; Uju et al., 2018; Waluyo et al., 2019). Hal ini menunjukkan kadar air yang diperoleh pada penelitian ini lebih baik dan sesuai dengan standar yang ditentukan.

Kadar abu rumput laut kering dari laut cukup tinggi yaitu $41,45 \pm 0,91 \%$ pada sampel kering dari laut, sedangkan terendah $9,17 \pm 0,84 \%$ pada agar dari tambak. Hasil yang diperoleh lebih tinggi dibandingkan nilai 20-23\% dari laut (Gressler et al., 2010; Ma'ruf et al., 2013; Musa et al., 2017) dan $7 \%$ dari tambak (Uju et al., 2018). Kadar abu yang diperoleh pada agar tepung tidak sesuai dengan standar baku mutu 6,5\% (BSN, 2015). Nilai abu yang diperoleh berbeda dari Jayasinghe et al., (2016) dengan kadar abu 4,28\%. Tingginya kadar abu dipengaruhi oleh kondisi perairan dari 
kedua lokasi dengan salinitas tinggi. Kadar abu sampel dari laut lebih tinggi karena salinitasnya tinggi dibandingkan di tambak. Rumput laut termasuk bahan pangan yang mengandung mineral cukup tinggi karena mampu menyerap mineral dari lingkungannya (Waluyo et al., 2019). Penyebab lainnya yaitu masih adanya sisa-sisa karang atau pasir yang terbawa karena kurang bersih saat pencucian.

Kadar protein rumput laut yang diperoleh cukup tinggi yaitu $8,59 \pm 0,26 \%$ sampel dari tambak dan terendah 6,64 $\pm 0,92 \%$ agar dari laut. Kandungan protein ini lebih rendah dari 10,8\% (Ortiz et al., 2009). Kadar protein mendekati kandungan 7,9\% (Erniati et al., 2016) dan melebihi agar G. verrucosa yaitu $6 \%$ (Jayasinghe et al., 2016). Kandungan protein menurun setelah ekstraksi. Hal tersebut diduga ekstraksi rumput laut dengan perebusan pra perlakuan non-alkali. Protein dapat rusak pada suhu tinggi yang menyebabkan perubahan struktur kimia (denaturasi) akibat adanya perebusan.

Kadar lemak yang diperoleh cukup rendah, dengan nilai tertinggi yaitu $0,63 \pm 0,13 \%$ pada agar dari laut dan terendah $0,39 \pm 0,12 \%$ pada sampel kering dari laut. Kandungan lemak $G$. domingensis dan G. birdiae (Gressler et al., 2010), serta G. crassa (Baghel et al., 2014) dilaporkan lebih dari $1,30 \%$. Hal tersebut menunjukkan lemak yang diperoleh pada kedua sampel kering lebih rendah. Kadar lemak yang diperoleh masih dalam kisaran 0,15-0,84\% (Ahmad et al., 2012). Kadar lemak agar tergolong rendah dibandingkan dari 1,5\% (Jayasinghe et al., 2016). Lemak bersifat sukar larut dalam air, sehingga rendahnya lemak diduga lemak tidak larut seluruhnya dalam proses ekstraksi. Kandungan lemak pada rumput laut tergolong rendah dan bervariasi terhadap jenis rumput laut serta cara ekstraksinya (Rodriguez-Montesinos et al., 2013). Kandungan lemak meningkat setelah ekstraksi dilakukan. Hal tersebut tidak sesuai (Hanif et al., 2016) bahwa bahan makanan yang direbus mengalami penurunan kadar lemak.

Karbohidrat yang diperoleh cukup tinggi dengan nilai $67,19 \pm 0,86 \%$ pada sampel kering dari tambak dan terendah $41,48 \pm 0,59 \%$ pada sampel kering dari laut. Kandungan karbohidrat yang diperoleh dari sampel kering hampir sama dengan nilai 66\% (Ortiz et al., 2009) dan G. corticata yaitu 43\% (Rohani-Ghadikolaei et al., 2012). Karbohidrat agar lebih tinggi dari G. verrucosa yaitu $53 \%$ (Jayasinghe et al., 2016).

Hasil analisa FTIR kedua agar yang diekstrak memiliki spektrum dengan pita serapan hampir sama. Pita serapan pada gelombang $4000-1500 \mathrm{~cm}^{-1}$ menunjukkan pada gelombang sekitar 3400 $\mathrm{cm}^{-1}$ terdapat gugus hidroksil berupa ikatan hidrogen $(\mathrm{O}-\mathrm{H})$. Gelombang sekitar $2900 \mathrm{~cm}^{-1}$ menunjukkan adanya gugus alkana $\left(\mathrm{CH}_{3}\right.$ atau $\left.\mathrm{CH}_{2}\right)$ berasosiasi dengan metoksil dan gelombang sekitar $1600 \mathrm{~cm}^{-1}$ terdapat gugus aldehida (-CHO). Pita serapan pada daerah sidik jari yaitu 1500$400 \mathrm{~cm}^{-1}$ menunjukkan pada gelombang sekitar $1380 \mathrm{~cm}^{-1}$ terdapat gugus ester sulfat dan gelombang sekitar $1070 \mathrm{~cm}^{-1}$ terdapat struktur senyawa galaktosa pada agar (Abidin et al., 2015).

Tabel 1. Hasil rendemen agar Gracilaria sp.

\begin{tabular}{lc}
\hline \multicolumn{1}{c}{ Lokasi Pengambilan Sampel } & Rendemen (\%) \\
\hline Pantai Pok Tunggal & $15,31 \pm 0,48$ \\
Tambak Rumput Laut Desa Randusanga & $14,00 \pm 0,15$ \\
\hline
\end{tabular}

Tabel 2. Analisis Proksimat Sampel Kering dan Agar Gracilaria sp.

\begin{tabular}{lcccc}
\hline \multirow{2}{*}{ Parameter } & \multicolumn{2}{c}{ Laut } & \multicolumn{2}{c}{ Tambak } \\
\cline { 2 - 5 } & Sampel Kering & Agar & Sampel Kering & Agar \\
\hline Kadar Air (\%) & $9,77 \pm 0,62$ & $15,40 \pm 0,59$ & $9,17 \pm 0,50$ & $15,16 \pm 0,44$ \\
Kadar Abu (\%) & $41,45 \pm 0,91$ & $13,30 \pm 0,93$ & $14,62 \pm 0,20$ & $9,17 \pm 0,84$ \\
Protein (\%) & $6,89 \pm 0,76$ & $6,64 \pm 0,92$ & $8,59 \pm 0,26$ & $8,31 \pm 0,11$ \\
Lemak (\%) & $0,39 \pm 0,12$ & $0,63 \pm 0,13$ & $0,43 \pm 0,1$ & $0,61 \pm 0,11$ \\
Karbohidrat (\%) & $41,48 \pm 0,59$ & $64,00 \pm 0,69$ & $67,19 \pm 0,86$ & $66,76 \pm 0,55$ \\
\hline
\end{tabular}




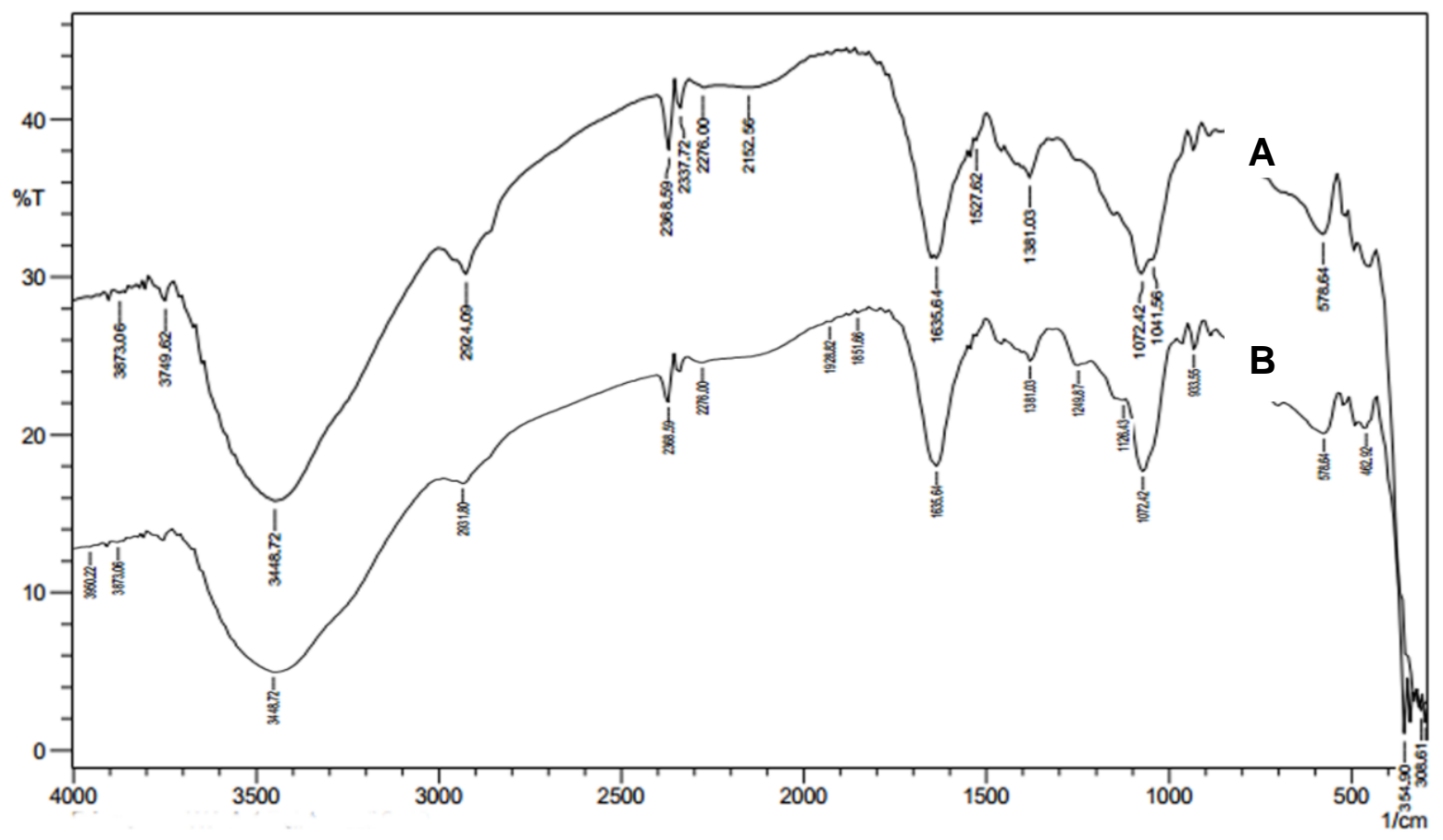

Gambar 1. Spektrum FTIR agar dari laut $(A)$ dan agar dari tambak (B)

Hasil analisis FTIR dari kedua lokasi menunjukkan perbedaan. Agar hasil ekstraksi dari tambak terlihat pada gelombang $1100 \mathrm{~cm}^{-1}$ terdapat gugus eter (C-O-C) dan pada $930 \mathrm{~cm}^{-1}$ terdapat gugus spesifik 3,6-anhydro-L-galaktosa, sedangkan pada agar hasil ekstraksi dari laut tidak terdeteksi. Hal ini kurang sesuai (Pereira et al., 2013) terdapat gugus spesifik 1,3- $\beta$-Dgalaktosa pada $890 \mathrm{~cm}^{-1}$ dan sulfat pada $860-830 \mathrm{~cm}^{-1}$. Gugus fungsi yang tidak terdeteksi diduga intensitas spektrum kedua analisis termasuk rendah. Hal tersebut ditunjukkan dari gugus utama agar yaitu galaktosa yang memiliki transmitan cukup tinggi senilai (19-27\%) agar dari laut dan (30$38 \%$ ) agar dari tambak. Rendahnya intensitas yang dihasilkan diduga lebih tingginya kadar abu pada agar hasil ekstraksi dari laut, sehingga beberapa gugus fungsi pada agar tidak terdeteksi.

Hasil diatas menunjukkan kedua hasil agar mengandung komposisi ekstraksi agar pada umumnya dengan adanya gugus galaktosa yaitu 3,6-anhydro-L-galaktosa (Rasheed et al., 2019). Agar yang dihasilkan lebih baik digunakan untuk industri makanan atau bahan reaktif dibandingkan untuk bahan bakteriologis karena masih ditemukannya metoksil dalam agar (Torres et al., 2019).

\section{KESIMPULAN}

Hasil penelitian menunjukkan adanya perbedaan pada rendemen, kadar air, kadar abu, kadar protein, kadar lemak, dan kadar karbohidrat sampel dari kedua lokasi yang berbeda. Agar yang diperoleh mengandung komposisi agar pada umumnya dan lebih baik digunakan untuk industri makanan atau bahan reaktif dibandingkan untuk bahan bakteriologis.

\section{UCAPAN TERIMAKASIH}

Artikel ini adalah bagian dari Skripsi yang berjudul "Kandungan Rendemen, Proksimat dan Analisis FTIR Hasil Ekstraksi Rumput Laut Gracilaria sp. Perlakuan Non Alkali dari Pantai Pok Tunggal dan Tambak Desa Randusanga" sebagai syarat memperoleh gelar Sarjana Strata Satu Program Studi IImu Kelautan Fakultas Perikanan dan IImu Kelautan, Universitas Diponegoro.

\section{DAFTAR PUSTAKA}

Abidin, Z., Rudyanto, M. \& Sudjarwo. 2015. Isolasi dan Karakterisasi Agarosa dari Rumput Laut Gracilaria verrucosa. Jurnal IImu Kefarmasian Indonesia, 13(1):69-75. 
Ahmad, F., Sulaiman, M.R., Saimon, W., Yee, C. F. \& Matanjun, P. 2012. Proximate Compositions and Total Phenolic Contents of Selected Edible Seaweed from Semporna, Sabah, Malaysia. Borneo Science, 31:85-96.

Ahmad, R., Surif, M., Ramli, N., Yahya, N., Nor, A.R.M \& Bekbayeva, L. 2011. A Preliminary Study on the Agar Content and Agar Gel Strength of Gracilaria manilaensis Using Different Agar Extraction Processes. World Applied Sciences Journal, 15(2):184-188.

Al-Nahdi, Z.N., Al-Alawi, A., Al-Marhobi, I. \& Al-Zefiti, A. 2015. Optimization of Yield and Chemical Properties of Agar Extracted from Melanothamnus somalensis from Oman Sea. Journal of Environmental Science and Engineering, B(4):302-314.

Ate, J.N.B., da Costa, J. F. \& Elingsetyo, T. P. 2017. Analisis Kandungan Nutrisi Gracilaria edule (S.G. Gmelin) P.C. Silva dan Gracilaria coronopifolia J. Agardh. Jurnal Ilmu Kesehatan, 5(2):94-103.

Badan Standarisasi Nasional (BSN). 2015. SNI 2802:2015 Agar-agar Tepung. Dewan Standarisasi Nasional. Jakarta. $14 \mathrm{hlm}$.

Baghel. R.S., Kumari, P., Reddy, C.R.K. \& Jha, B. 2014. Growth, Pigments, and Biochemical Composition of Marine Red Alga Gracilaria crassa. Journal Applied Phycology, 26(5):21432150.

Cirik, S., Cetin, Z., Ak, I., Cirik, S. \& T. Göksan. 2010. Greenhouse Cultivation of Gracilaria verrucosa (Hudson) Papenfuss and Determination of Chemical Composition. Turkish Journal of Fisheries and Aquatic Sciences, 10:559-564.

Diana, F., Nirmala, K. \& Soelistyowati, D.T. 2014. Analisis Kualitas Rumput Laut Gracilaria gigas yang Dibudidaya pada Habitat Laut dan Tambak, Nusa Tenggara Barat. Jurnal Ris. Akuakultur, 9(1):59-65.

Erniati., Zakaria, F.R., Prangdimurti, E. \& Adawiyah, D.R. 2016. Potensi Rumput Laut: Kajian Komponen Bioaktif dan Pemanfaatannya sebagai Pangan Fungsional. Aquatic Sciences Journal, 3(1):12-17.

Gressler, V., Yokoya, N.S., Fujii, M.T., Colepicolo, P., Filho, J.M., Torres, R.P. \& Pinto, E. 2010. Lipid, Fatty Acid, Protein, Amino Acid and Ash Contents in Four Brazilian red Algae Species. Food Chemistry, 120:585-590.

Hanif, N., Hasanah, R. \& Kusumaningrum, I. 2016. Pengaruh Lama Perebusan Terhadap Karakteristik Tepung Tulang Ikan Belida (Chitala lopis). Jurnal IImu Perikanan Tropis, 21(2):72-79.

Hernandez-Carmona, G., Freile-Pelegrin, Y. \& Hernandez-Garibay, E. 2013. Conventional and Alternative Technologies for The Extraction of Algal Polysaccharides. Woodhead Publishing., pp. 475-516.

Ibrahim, H.A.H., Beltagy, E.A., El-Din, N.G.S., Zokm, G.M.E., El-Sikaily, A.M. \& Abu-Elela, G.M. 2015. Seaweeds Agarophytes and Associated Epiphytic Bacteria Along Alexandria Coastline, Egypt, with Emphasis on The Evaluation and Extraction of Agar and Agarose. Revista de Biologia Marina y Oceanografia, 50(3):545-561.

Jayasinghe, P.S., Pahalawattarachci, V. \& Ranaweera, K.K.D. S. 2016. Effect of Extraction Methods on the Yield and Physiochemical Properties of Polysaccharides Extracted from Seaweed Available in Sri Lanka. Poultry, Fisheries \& Wildlife Sciences, 4:1-6.

Kasimala, M.B., Mebrahtu, L., Mehari, A. \& Negasi, T.K. 2017. Proximate Composition of Three Abundant Species of Seaweeds from Red Sea Coast in Massawa, Eritrea. Journal Algal Biomass UtIn, 8(2):44-49.

Lee, W. K., Lim, P.E., Phang, S. M. \& Namasivayam, P. 2016. Agar Properties of Gracilaria species (Gracilariaceae, Rhodophyta) Collected from Different Natural Habitats in Malaysia. Regional Studies in Marine Science, 7:123-128.

Ma'ruf, W. F., Ibrahim, R., Dewi, E. N., Susanto, E. \& Amalia, U. 2013. Profil Rumput Laut Caulerpa racemosa dan Gracilaria verrucosa sebagai Edible Food. Jurnal Saintek Perikanan, 9(1):68-74.

Musa, S., Sanger, G. \& Dien, H. A. 2017. Komposisi Kimia, Senyawa Bioaktif dan Angka Lempeng Total pada Rumput Laut Gracilaria edulis. Jurnal Media Teknologi Hasil Perikanan, 5(3):184189. 
Ortiz, J., Uquiche, E., Robert, P., Romero, N., Quitral, V. \& Lianten, C. 2009. Functional and Nutritional Value of The Chilean Seaweeds Codium fragile, Gracilaria chilensisi and Macrocystis pyrifera. Europe Journal of Lipid Science and Tech, 111:320-327.

Pereira, L., Gheda, S.F., Ribeiro-Claro, P.J.A. 2013. Analysis by Vibrational Spectroscopy of Seaweed Polysaccharides with Potential Use in Food, Pharmaceutical, and Cosmetic Industries. International Journal of Carbohydrate Chemistry, 22:1-7.

Rasheed, I., Tabassum, A., Khan, U. \& Rehman, A. 2019. Fourier Transform Infrared (FT-IR) Spectroscopy of Agar from Red Seaweeds of Karachi Coast. Int.J.Biol.Biotech, 16(1):59-63.

Rhein-Knudsen, N., Ale, M.T., Ajalloueian, F., Yu, L. \& Meyer, A.S. 2017. Rheological Properties of Agar and Carageenan from Ghanaian Red Seaweeds. Food Hydrocolloids, 63:50-58.

Rodriguez-Montesinos, Y. E., Arvizu-Higurea, D. L., Hernandez-Carmona, G., Munoz-Ochoa, M. \& Murillo-Alvarez, J. I. 2013. Seasonal Variation of The Agar Quality and Chemical Composition of Gracilaria veleroae and Gracilaria vermiculophylla (Rhodophyceae, Gracilariaceae) from Baja California Sur, Mexico. Phycological Research, 61:116-123.

Rohani-Ghadikolaei, K., Abdulalian, E. \& Wing-Kong, N. 2012. Evaluation of The Proximate, Fatty Acid and Mineral Composition of Representative Green, Brown and Red Seaweeds from The Persian Gulf of Iran as Potential Food and Feed Resources. Journal Food Sci Technol, 49(6):774-780.

Sahu, N \& Sahoo, D. 2013. Study of Morphology and Agar Contents in Some Important Gracilaria Spesies of Indian Coasts. American Journal of Plant Sciences, 4:52-59.

Santika, L. G., Ma'aruf, W.F. \& Romadhon. 2014. Karakteristik Agar Rumput Laut Gracilaria verrucosa Budidaya Tambak dengan Perlakuan Konsentrasi Alkali pada Umur Panen yang Berbeda. Jurnal Pengolahan dan Bioteknologi Hasil Perikanan, 3(4):98-105.

Saraswaty, V., Mozel, T., Risdian, C. \& Rasyid, A. 2015. Bioactivity of Polysaccharide from Gracilaria verrucosa as a-Glucoside Inhibitor. Procedia Chemistry, 16:687-693.

Torres, M. D., Florez-Fernandez, N. \& Domininguez, H. 2019. Integral Utilization of Red Seaweed for Bioactive Production. Marine Drugs, 17: 1-34.

Uju, U., Santoso, J., Ramadhan, W. \& Abrory, M.F. 2018. Ekstraksi Native Agar dari Rumput Laut Gracilaria sp. dengan Akselerasi Ultrasonifikasi pada Suhu Rendah. Jurnal Pengolahan Hasil Perikanan Indonesia, 21(3):414-422.

Villanueva, R.D. \& Montano, M.N.E. 2014. Enhancement of Carageenan Gel Quality in The Commercially Important Tropical Seaweed Eucheuma denticulatum (Rhodophyta), with Postharvest Treatment in Low-Nutrient Conditions. Botanica Marina, 57(3):217-223.

Villanueva, R.D., Sousa, A.M.M., Goncalves, M.P. \& Nilsson, M. 2010. Production and Properties of Agar from The Invasive Marine Alga, Gracilaria vermiculophylla (Gracilariales, Rhodophyta). Journal of Applied Phycology, 22(2): 211-220.

Waluyo., Permadi, A., Fanni, N.A. \& Soedrijanto, A. 2019. Analisis Kualitas Rumput Laut Gracilaria verrucosa di Tambak Kabupaten Karawang, Jawa Barat. Journal Grouper, 10(1):32-41.

Yarnpakdee, S., Benjakul, S. \& Kingwascharapong, P. 2015. Physico-Chemical and Gel Properties of Agar from Gracilaria tenuistipitata from The Lake of Songkhla, Thailand. Food Hydrocolloids, 51:217-226.

Yousefi, M. K., Islami, H.R. \& Filizadeh, Y. 2013. Effect of Extraction Process on Agar Properties of Gracilaria corticata (Rhodophyta) Collected from The Persian Gulf. Phycologya, 52(5):481487. 